\title{
Birds of Serra da Capivara National Park, in the "caatinga" of north-eastern Brazil
}

\author{
FÁBIO OLMOS
}

\section{Summary}

Serra da Capivara National Park covers an area of about $1,300 \mathrm{~km}^{2}$ in south-eastern Piauí, north-eastern Brazil. The park's vegetation is the endemic caatinga, with a few remnants of semi-deciduous forest in some canyons. The area has a reasonable diversity of plants, with 615 catalogued species. Since 1986, 208 bird species have been observed in the park and its buffer zone, including to threatened or near-threatened species, plus two recently extinct in the area. Other species are regionally rare and have declined over parts of their distribution. The park also harbours several threatened mammals and caatinga endemics. Despite having been created in 1979 the park remains effectively unprotected and unmanaged. Current levels of poaching and habitat destruction prejudice the future of several species, including some that have already vanished from other parts of the caatinga.

O Parque Nacional da Serra da Capivara abrange uma área de aproxidamamente $1,300 \mathrm{~km}^{2}$ no sudeste do Piauí, nordeste do Brasil. A vegetação do parque é a caatinga, com alguns enclaves de mata semi-decídua. A área possui uma razoável diversidade de plantas, com um total de 615 espécies já catalogadas. Desde 1986 , um total de 208 espécies de aves foram observadas no parque e sua zona-tampão, incluindo 10 consideradas ameaçadas ou quase-ameaçadas, além de duas recentemente extintas na área. Outras espécies são regionalmente raras ou tem declinado em parte de sua área de distribuição. $\mathrm{O}$ parque também abriga diversos mamíferos ameaçados, e endemismos da caatinga. Apesar de ter sido criado em 1979, o parque ainda não foi consolidado e é pouco mais que um parque de papel. Com os presentes niveis de caça clandestina e destruição de habitats, diversas espécies se extinguirão, incluindo algumas já desaparecidas de outras partes da caatinga.

\section{Introduction}

The caatinga is a vast semi-arid biome comprising most of north-eastern Brazil, roughly the area between $35^{\circ}$ and $45^{\circ} \mathrm{W}$ and $3^{\circ}$ and $16^{\circ} \mathrm{S}$ (Reis 1976). This area is the largest dry region within the Neotropical region and is bordered by much more mesic habitats (Markhan 1972, Reis 1976). The entire biome is subject to periods of pronounced aridity, when annual rainfall does not exceed $200 \mathrm{~mm}$ and may be zero (Markhan 1972).

The vegetation of this semi-arid region is composed of different xeric, deciduous plant assemblages, which are collectively known as "caatinga". There is a large degree of endemism among the plants (Lima 1960, Hayashi 1973, Hayashi and Numata 1976, Emperaire 1989). 
There appear to be few endemic vertebrates in the caatinga (Mares et al. 1985) but in fact undescribed taxa are still regularly discovered, especially amongst the reptiles (see Manzani and Abe 1990, Rodrigues 1991a-d, Vanzolini 1991a,b).

Since colonization in the 1700 , the caatinga has been heavily altered, the low and open present-day bush being derived from a more forest-like assemblage (Webb 1974, Sarmiento 1976). Arboreal caatinga still survives in a few areas, especially in Piauí.

As a whole the conservation of the caatinga has been neglected, only $0.1 \%$ of it being protected by national parks and other reserves $(\mathrm{M}$. T. Jorge-Padua

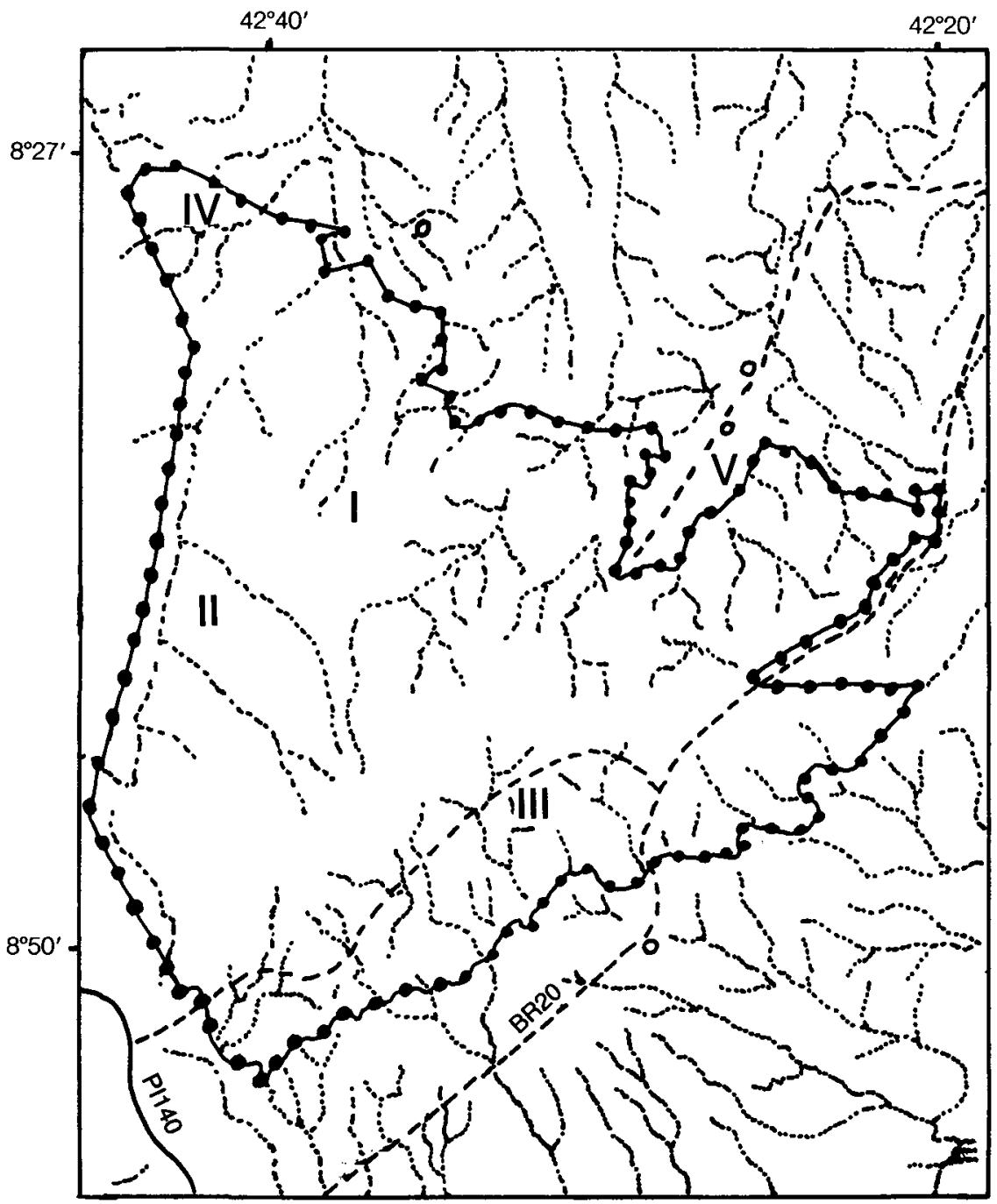

Figure 1. Map of Serra da Capivara National Park, south-eastern Piauí, Brazil. The heavy dotted line shows the park's limits. Open circles are villages. All roads in the region, including BR 20, are unpaved, except for PI 140. Places mentioned in the text are I, Gongo; II, Serra Branca; III, Zabele; IV, Angical; V, Varedão. 
verbally 1991; also IBAMA 1989a). This paper presents information on the species composition and conservation status of the bird community of one of the largest of such reserves, Serra da Capivara National Park.

\section{Study area and methods}

Serra da Capivara National Park was created in 1979 mainly to protect the rich archaeological sites in the region, among the oldest known in America (Guidon and Delibrias 1986). The park is located in south-eastern Piauí, between $8^{\circ} 30^{\prime}-$ $8^{\circ} 5^{\prime} \mathrm{S}$ and $42^{\circ} 20^{\prime}-42^{\circ} 50^{\prime} \mathrm{W}$, and has a total area of 129,140 ha (Figure 1 ).

Basically the park covers a sandstone plateau ("chapada") with cliffs $50-$ $200 \mathrm{~m}$ high, dissected by a few valleys and narrow canyons. Soils on the chapada are yellow-red latossols, while in the valleys and canyons they are of white sand, except in the canyon of Varedão, at the north-eastern border of the park (Figure 1), which has argillous soil. Along the border of the chapada there are large areas of eroded rock and shallow soil.

Climate is semi-arid, with a mean annual temperature of $28^{\circ} \mathrm{C}$ and low thermic range. Annual precipitation is variable, between 250 and 1,260 mm, with a trend to the lower value. Most rain falls between September and March, but timing and amount are unpredictable (Emperaire 1989). There are no perennial watercourses in the park, only some waterholes and springs. There are a few manmade reservoirs, the largest of which is at Zabelê, an abandoned village in the park.

The park's vegetation has been described in detail by Emperaire (1989), who found 615 plant species and defined eight plant assemblages. Here I simply her classification (as the differences among them are not always clear in the field), and distinguish five main vegetation types:

1. Arboreal-arbustive caatinga covers most of the park, has a high diversity of species, and consists mostly of tangled bushes and trees up to $10 \mathrm{~m} \mathrm{high}$. It is barely penetrable as most woody plants are heavily ramified from the base.

2. Arboreal caatinga is mainly restricted to the west of the park. Trees are up to $12 \mathrm{~m}$ high and there is a more open undergrowth.

3. Angical is an open woodland mainly of 12-15 m high "angico" trees Anadenanthera macrocarpa. Best examples are in the south of the park, near Zabelê.

4. Second-growth caatinga represents a species-poor assemblage which forms after cultivation or burning. Depending on the soil type it is dominated by Croton sonderianus or Piptadenia obliqua-Mimosa acutistipula up to four metres high.

5. Semi-deciduous forest, restricted to the narrower canyons, has tall (up to $30 \mathrm{~m}$ ) trees with straight and sparsely branched trunks and almost no undergrowth.

Bird surveys were conducted all over the park in December 1986; July 1987; July and December 1989; and March through May and July 1991. Birds were censused and identified with the aid of binoculars and tape-recordings provided by the Arquivo Sonoro Neotropical (UNICAMP). A few individuals were mistnetted, especially nightjars.

The area around the park was also surveyed, especially Fazenda Veneza 
$\left(8^{\circ} 45^{\prime} \mathrm{S} 42^{\circ} 16^{\prime} \mathrm{W}\right)$, where there is a large artificial reservoir, and Lagoa do Muquem $\left(8^{\circ} 24^{\prime} 30^{\prime \prime} \mathrm{S} 42^{\circ} 22^{\prime} 20^{\prime \prime} \mathrm{W}\right)$, a lagoon in the Rio Piaui basin subject to wide water-level variations and even complete drying-out (Olmos and Souza 1991). Brazilian law considers a $10 \mathrm{~km}$ stretch around any federal reserve as an "environmental conservation area" where human activity is, in theory, controlled (Federal Decree 99,274 of 6 June 1990).

For listing the species I used some of the criteria of Stotz and Bierregaard (1989) for abundance and sociality (Table 1).

\section{Results}

Observations and captures in and around the park resulted in a list of 208 species of birds, of which 179 are known from within the park (Table 1). Most species not observed in the park are waterbirds for which there is little habitat, although some species like sandpipers and ducks frequently use the reservoir at Zabelê. As expected in a highly seasonal environment, the populations of some species suffer wide fluctuations and may be present during part of the year only. This is true for waterbirds and most granivorous ones, including some icterids, doves and seedeaters. The status column of Table 1 indicates the average abundance of a species when it is present in the region.

Table 1. Birds of Serra da Capivara National Park, Brazil

\begin{tabular}{|c|c|c|c|}
\hline Species & Habitat & Status & Sociality \\
\hline Crypturellus noctivagus* & $1,2,3,4$ & C & $\mathrm{s}$ \\
\hline Crypturellus parvirostris* & $1,3,4$ & C & $\mathrm{S}$ \\
\hline Crypturellus tataupa* & 1,2 & F & $\mathrm{s}$ \\
\hline Nothura boraquira* & 4 & C & $\mathrm{S}$ \\
\hline Podiceps dominicus & 6 & $x$ & $\mathrm{~S}$ \\
\hline Phalacrocorax olivaceus & 6 & $x$ & $\mathrm{~S}, \mathrm{M}$ \\
\hline Anhinga anhinga & 6 & $x$ & $\mathrm{~S}$ \\
\hline Ardea cocoi & 6 & $x$ & $\mathrm{~S}$ \\
\hline Casmerodius albus* & 6 & $x$ & S,M \\
\hline Egretta thula & 6 & $x$ & $\mathrm{M}, \mathrm{U}$ \\
\hline Butorides striatus* & 6 & $x$ & $\mathrm{~S}$ \\
\hline Bubulcus ibis & 6 & $x$ & $M, U$ \\
\hline Syrigma sibilatrix & 6 & $x$ & $S, U$ \\
\hline Nycticorax nycticorax & 6 & $x$ & S,M \\
\hline Tigrisoma lineatum & 6 & $x$ & $\mathrm{~S}$ \\
\hline Ixobrychus involucris & 6 & $x$ & $S$ \\
\hline Mycteria americana & 6 & $x$ & $\mathbf{M}$ \\
\hline Dendrocygna viduata* & 6 & $x$ & $\mathbf{M}$ \\
\hline Dendrocygna autumnalis & 6 & $x$ & $\mathrm{~s}$ \\
\hline Amazonetta brasiliensis* & 6 & $x$ & $\mathbf{M}$ \\
\hline Cairina moschata* & 6 & $x$ & $\mathrm{~s}$ \\
\hline Sarcoramphus papa* & 7 & $\mathbf{R}$ & $\mathrm{S}$ \\
\hline Coragyps atratus* & 7 & C & $\mathrm{S}$ \\
\hline Cathartes aura* & 7 & $\mathbf{F}$ & $\mathrm{S}$ \\
\hline Cathartes burrovianus* & 7 & C & $\mathrm{s}$ \\
\hline Gampsonyx swainsonii ${ }^{*}$ & $1,2,4$ & $\mathrm{R}$ & $\mathrm{S}$ \\
\hline Ictinia plumbea* & $1,4,5$ & $x$ & $\mathrm{~s}$ \\
\hline Accipiter bicolor* & 1,2 & $x$ & $\mathrm{~S}$ \\
\hline
\end{tabular}


Table 1 (cont.)

\begin{tabular}{|c|c|c|c|}
\hline Species & Habitat & Status & Sociality \\
\hline Geranoaetus melanoleucos* & 7 & $\mathrm{R}$ & $\mathrm{S}$ \\
\hline Buteo albicaudatus* & 7 & $\mathrm{R}$ & $\mathrm{S}$ \\
\hline Buteo albonotatus* & 7 & $\mathrm{R}$ & $S$ \\
\hline Buteo swainsoni* & 7 & $x$ & M \\
\hline Buteo brachyurus* & 7 & $\mathrm{R}$ & $S$ \\
\hline Buteo magnirostris* & $1,2,3,4,7$ & $\mathrm{C}$ & $\mathrm{s}$ \\
\hline Heterospizias meridionalis ${ }^{*}$ & 1,4 & $\mathbf{R}$ & $\mathrm{s}$ \\
\hline Geranospiza caerulescens* & 1,7 & $\mathbf{R}$ & S \\
\hline Herpetotheres cachinnans* & $1,4,5,7$ & $\mathbf{F}$ & $\mathrm{S}$ \\
\hline Micrastur ruficollis* & $1,2,5$ & F & $\mathrm{s}$ \\
\hline Milvago chimachima* & 1 & $x$ & $\mathrm{~S}$ \\
\hline Polyborus plancus* & $1,2,3,4,7$ & F & s \\
\hline Falco femoralis* & $1,5,7$ & $\mathrm{R}$ & s \\
\hline Falco sparoerius* & $1,2,3,4,7$ & F & $S$ \\
\hline Penelope superciliaris* & $1,2,4,5$ & $\mathrm{U}$ & $\mathrm{S}, \mathrm{M}$ \\
\hline Penelope jacucaca* & $1,2,4,5$ & $\mathrm{U}$ & $\mathrm{S}, \mathrm{M}$ \\
\hline Aramus guarauna & 6 & $x$ & $\mathrm{~S}$ \\
\hline Aramides cajanea* & 4 & $x$ & S \\
\hline Porzana albicollis & 6 & $x$ & $\mathrm{~s}$ \\
\hline Laterallus melanophaius & 6 & $x$ & S \\
\hline Gallinula chloropus* & 6 & $x$ & S \\
\hline Porphyrula martinica & 6 & $x$ & S \\
\hline Cariama cristata* & $1,3,4$ & $\mathrm{~F}$ & $\mathrm{~s}$ \\
\hline Jacana jacana* & 6 & $x$ & $\mathrm{~s}$ \\
\hline Vanellus chilensis* & 4,6 & $x$ & $\mathrm{~s}$ \\
\hline Hoploxypterus cayanus* & 6 & $x$ & $\mathbf{M}$ \\
\hline Tringa solitaria* & 6 & $x$ & $\mathrm{~S}$ \\
\hline Tringa flavipes & 6 & $x$ & $\mathbf{M}$ \\
\hline Actitis macularia* & 6 & $x$ & $\mathrm{~S}$ \\
\hline Himantopus himantopus & 6 & $x$ & $\mathbf{M}$ \\
\hline Columba picazuro* & $1,2,3,4$ & C & S,M \\
\hline Zenaida auriculata* & $1,2,3,4$ & $\mathrm{C}$ & $\mathbf{M}$ \\
\hline Columbina minuta & $1,2,3,4$ & F & $\mathrm{S}, \mathrm{M}$ \\
\hline Columbina talpacoti* & $1,2,3,4$ & $\mathrm{C}$ & $\mathrm{S}, \mathrm{M}$ \\
\hline Columbina picui* & $1,2,3,4$ & C & $\mathrm{S}, \mathrm{M}$ \\
\hline Claravis pretiosa* & $1,2,3,4,5$ & $\mathrm{C}$ & S,M \\
\hline Scardafella squammata* & $1,2,3,4$ & $\mathrm{C}$ & S,M \\
\hline Leptotila verreauxi* & $1,2,3,4,5$ & C & $\mathrm{S}$ \\
\hline Ara chloroptera* & $1,2,7$ & $\mathrm{U}$ & $S, M$ \\
\hline Ara maracana* & 4,5 & $\mathbf{R}$ & $S$ \\
\hline Aratinga leucophthalmus* & 1,4 & $\mathbf{R}$ & S,M \\
\hline Aratinga cactorum* & $1,2,3,4$ & $C$ & $\mathbf{M}$ \\
\hline Forpus xanthopterygius & 4 & $x$ & $\mathbf{M}$ \\
\hline Amazona aestiva* & $1,2,3,4,5$ & $\mathrm{~F}$ & S,M \\
\hline Coccyzus melacoryphus* & $1,2,4$ & F & $\mathrm{S}$ \\
\hline Piaya cayana* & $1,2,5$ & $\mathrm{U}$ & S \\
\hline Crotophaga major* & 2,4 & $x$ & M \\
\hline Crotophaga ani* & 1,4 & $\mathrm{C}$ & $\mathbf{M}$ \\
\hline Guira guira* & 1,4 & $\mathrm{C}$ & $\mathbf{M}$ \\
\hline Tapera naevia* & $1,2,4$ & F & $\mathrm{S}$ \\
\hline Dromococcyx phasianellus* & 1,2 & $\mathrm{U}$ & $\mathrm{S}$ \\
\hline Tyto alba* & 1,5 & $\mathrm{U}$ & S \\
\hline Otus choliba* & $1,4,5$ & $F$ & $S$ \\
\hline
\end{tabular}


Table 1 (cont.)

\begin{tabular}{|c|c|c|c|}
\hline Species & Habitat & Status & Sociality \\
\hline Bubo virginianus* & 5 & $\times$ & $\mathbf{S}$ \\
\hline Glaucidium brasilianum* & $1,2,3$ & $\mathrm{~F}$ & $\mathrm{~S}$ \\
\hline Nyctibius griseus ${ }^{*}$ & 1,5 & $\mathrm{U}$ & $\mathrm{S}$ \\
\hline Podager nacunda & 4,7 & C & S,M \\
\hline Chordeiles pusillus* & $1,5,7$ & C & $\mathrm{S}$ \\
\hline Nyctidromus albicollis* & 4 & $x$ & $\mathrm{~S}$ \\
\hline Caprimulgus rufus* & $\mathbf{1}$ & $\mathrm{F}$ & $\mathrm{S}$ \\
\hline Caprimulgus paroulus* & $1,2,4$ & C & S,M \\
\hline Caprimulgus hirundinaceus ${ }^{*}$ & $1,2,4,5$ & $\mathrm{~F}$ & S,M \\
\hline Hydropsalis brasiliana* & $1,2,4$ & $\mathrm{~F}$ & $\mathrm{~S}$ \\
\hline Streptoprocne zonaris* & 7 & C & $\mathbf{M}$ \\
\hline Streptoprocne biscutata* & 7 & C & $\mathbf{M}$ \\
\hline Reinarda squamata & 7 & $\times$ & $\mathrm{M}$ \\
\hline Phaethornis nattereri* & $1,2,4,5$ & $\mathrm{U}$ & $\mathrm{S}$ \\
\hline Phaethornis gounellei* & $1,2,4,5$ & $\mathrm{U}$ & $\mathrm{S}$ \\
\hline Eupetomena macroura* & $\mathbf{I}$ & $x$ & $S$ \\
\hline Colibri serrirostris ${ }^{*}$ & $\mathbf{I}$ & $x$ & $\mathrm{~S}$ \\
\hline Chrysolampis mosquitus* & $1,2,3,4,5$ & $\mathrm{~F}$ & $\mathrm{~S}$ \\
\hline Chlorostilbon aureoventris* & $1,2,3,4$ & $\mathrm{~F}$ & $\mathrm{~S}$ \\
\hline Calliphlox amethystina ${ }^{*}$ & $1,2,5$ & $\mathrm{U}$ & $\mathrm{D}$ \\
\hline Ceryle torquata & 6 & $\mathrm{R}$ & S \\
\hline Chloroceryle amazona & 6 & $x$ & $\mathrm{~S}$ \\
\hline Chloroceryle americana & 6 & $\mathbf{R}$ & $\mathrm{S}$ \\
\hline Trogon curucui* & $1,2,5$ & $\mathrm{~F}$ & $S, U$ \\
\hline Galbula ruficauda* & $1,2,4$ & $\mathrm{R}$ & $\mathrm{S}$ \\
\hline Nystalus maculatus* & $1,2,4,5$ & $\mathrm{~F}$ & $\mathrm{~S}$ \\
\hline Picumnus limae & 4 & $x$ & $\mathrm{~S}$ \\
\hline Picumnus pygmaeus* & 1,2 & $R$ & $\mathrm{~S}, \mathrm{U}$ \\
\hline Chrysoptilus melanochloros* & $1,2,3,5$ & $\mathrm{U}$ & $\mathrm{S}$ \\
\hline Celeus flavescens* & $1,2,3$ & $\mathrm{U}$ & $\mathrm{S}$ \\
\hline Dryocopus lineatus* & $1,3,5$ & $\mathrm{R}$ & $\mathrm{S}$ \\
\hline Veniliornis passerinus* & $1,2,3,5$ & $\mathbf{F}$ & $\mathrm{S}, \mathrm{U}$ \\
\hline Phloeoceastes melanoleucos & 3,5 & $\mathrm{R}$ & $\mathrm{S}$ \\
\hline Sittasomus griseicapillus* & 3,5 & $\mathrm{R}$ & S,U \\
\hline Dendrocolaptes platyrostris* & $1,2,3,5$ & $\mathbf{F}$ & $\mathrm{S}, \mathrm{U}$ \\
\hline Lepidocolaptes angustirostris & $1,2,3,5$ & $\mathrm{~F}$ & $\mathrm{~S}, \mathrm{U}$ \\
\hline Campylorhamphus trochilirostris * & $1,2,5$ & $\mathrm{U}$ & $\mathrm{S}, \mathrm{U}$ \\
\hline Furnarius leucopus* & 1,4 & $\mathrm{U}$ & $\mathrm{S}$ \\
\hline Furnarius figulus* & 1,4 & $\mathrm{U}$ & $\mathrm{S}$ \\
\hline Synallaxis ruficapilla* & 1,2 & $\mathrm{U}$ & $\mathrm{S}, \mathrm{U}$ \\
\hline Synallaxis frontalis* & 1,2 & $\mathrm{U}$ & S,U \\
\hline Synallaxis albescens* & 1,2 & $\mathrm{~F}$ & $\mathrm{~S}, \mathrm{U}$ \\
\hline Gyalophylax hellmayri* & $\mathbf{1}$ & $\mathbf{R}$ & $\mathrm{S}$ \\
\hline Certhiaxis cinnamomea & 6 & $x$ & $\mathrm{~S}$ \\
\hline Poecilurus scutatus* & $1,2,5$ & $\mathrm{R}$ & $\mathrm{S}, \mathrm{U}$ \\
\hline Pseudoseisura cristata ${ }^{*}$ & 1,4 & $\mathrm{U}$ & $\mathrm{S}$ \\
\hline Megaxenops parnaguae & $I, 2,4$ & $\mathrm{~F}$ & $\mathrm{~S}$ \\
\hline Taraba major* & $1,2,3,4$ & $\mathrm{~F}$ & $\mathrm{~S}, \mathrm{U}$ \\
\hline Sakesphorus cristatus* & $1,2,4$ & $\mathrm{~F}$ & $\mathrm{~S}, \mathrm{U}$ \\
\hline Thamnophilus doliatus* & $1,2,3,4$ & $\mathbf{F}$ & $\mathrm{S}, \mathrm{U}$ \\
\hline Thamnophilus punctatus ${ }^{*}$ & $1,2,3,4,5$ & $\mathrm{C}$ & $\mathrm{S}, \mathrm{U}$ \\
\hline Myrmorchilus strigilatus* & $1,2,3,4,5$ & $F$ & $\mathrm{~S}, \mathrm{U}$ \\
\hline Herpsilochmus pileatus* & $1,2,4,5$ & $\mathrm{~F}$ & $\mathrm{~S}, \mathrm{U}$ \\
\hline
\end{tabular}


Table 1 (cont.)

\begin{tabular}{|c|c|c|c|}
\hline Species & Habitat & Status & Sociality \\
\hline Formicivora grisea ${ }^{*}$ & 1 & $\mathbf{R}$ & $\mathrm{S}$ \\
\hline Formicivora melanogaster & $1,2,4,5$ & C & $\mathrm{S}, \mathrm{U}$ \\
\hline Hylopezus ochroleucus ${ }^{*}$ & $1,2,5$ & $\mathrm{~F}$ & S,U \\
\hline Platypsaris rufus* & 1,5 & $\mathrm{R}$ & $S, U$ \\
\hline Pachyramphus polychopterus ${ }^{*}$ & $1,2,5$ & $\mathbf{U}$ & S,U \\
\hline Xolmis irupero & 4 & $x$ & $S$ \\
\hline Fluvicola pica & 6 & $x$ & $S$ \\
\hline Fluvicola negenta* & 6 & $x$ & $\mathrm{~S}$ \\
\hline Arundinicola leucocephala & 6 & $x$ & $\mathrm{~S}$ \\
\hline Satrapa icterophrys* & 4 & $x$ & $\mathrm{~S}$ \\
\hline Machetornis rixosus & 4 & $\mathbf{U}$ & $\mathrm{S}$ \\
\hline Tyrannus melancholicus* & $1,2,3,4$ & C & $\mathrm{S}, \mathrm{U}$ \\
\hline Empidonomus varius* & 1,4 & $\mathbf{R}$ & $S$ \\
\hline Megarhynchus pitangua & $1,2,4,5$ & $\mathrm{~F}$ & $S, U$ \\
\hline Myiodynastes maculatus* & $1,2,5$ & $\mathrm{~F}$ & $\mathrm{~S}, \mathrm{U}$ \\
\hline Myiozetetes similis* & $1,2,4$ & $\mathbf{R}$ & $\mathrm{S}, \mathrm{U}$ \\
\hline Pitangus sulphuratus* & $1,2,4$ & $F$ & $S, U$ \\
\hline Pitangus lictor & 6 & $\mathbf{R}$ & $S$ \\
\hline Casiornis fusca* & $1,2,4$ & $\mathbf{R}$ & $\mathrm{S}, \mathrm{U}$ \\
\hline Myiarchus tyrannulus ${ }^{*}$ & $1,2,3,4,5$ & $\mathrm{C}$ & $S, U$ \\
\hline Empidonax euleri & 1 & $\mathbf{R}$ & $S$ \\
\hline Myiobius cf. barbatus* & 1,2 & $\mathbf{R}$ & $\mathrm{S}, \mathrm{U}$ \\
\hline Tolmomyias flaviventris ${ }^{*}$ & $1,2,3,4,5$ & $\mathrm{R}$ & $\mathrm{S}, \mathrm{U}$ \\
\hline Hirundinea ferruginea* & 1 & C & $\mathrm{S}$ \\
\hline Todirostrum cinereum* & $1,2,3,4,5$ & $\mathrm{~F}$ & $\mathrm{~S}, \mathrm{U}$ \\
\hline Idioptilon margaritaceiventer ${ }^{*}$ & $1,2,3,4,5$ & $F$ & S,U \\
\hline Euscarthmus meloryphus ${ }^{*}$ & 1,4 & $F$ & $\mathrm{~S}, \mathrm{U}$ \\
\hline Serpophaga subcristata* & 5 & $\times$ & $\mathrm{S}$ \\
\hline Elaenia flavogaster* & 1 & $x$ & $\mathrm{~S}$ \\
\hline Myiopagis viridicata* & $1,2,3,4,5$ & C & $S, U$ \\
\hline Camptostoma obsoletum* & 1,2 & $\mathrm{~F}$ & $\mathrm{~S}$ \\
\hline Phyllomyias fasciatus* & $1,2,4$ & $\mathbf{R}$ & $\mathrm{S}$ \\
\hline Leptopogon amaurocephalus & 2,4 & $\mathbf{R}$ & $\mathrm{S}$ \\
\hline Tachycineta albiventer & 6 & $x$ & $S$ \\
\hline Progne chalybea* & 7 & $\mathrm{C}$ & $\mathbf{M}$ \\
\hline Stelgidopteryx ruficollis ${ }^{*}$ & 7 & $x$ & $S$ \\
\hline Troglodytes aedon* & $1,2,5$ & $\mathrm{~F}$ & $\mathrm{~S}, \mathrm{U}$ \\
\hline Mimus saturninus* & 1,4 & $\mathrm{C}$ & $\mathrm{M}, \mathrm{U}$ \\
\hline Turdus rufiventris* & $1,2,4,5$ & $\mathrm{U}$ & S,U \\
\hline Turdus leucomelas* & $2,3,5$ & $\mathrm{~F}$ & $S, U$ \\
\hline Turdus amaurochalinus* & $2,3,5$ & $\mathrm{U}$ & $\mathrm{S}$ \\
\hline Polioptila plumbea* & $1,2,3,4,5$ & $F$ & $S, U$ \\
\hline Cyclarhis gujanensis* & $1,2,3,5$ & $\mathrm{U}$ & S,U \\
\hline Vireo olivaceus ${ }^{*}$ & 2,5 & $\mathbf{R}$ & $S$ \\
\hline Hylophilus poicilotis* & 1,4 & $x$ & $\mathrm{~S}, \mathrm{U}$ \\
\hline Molothrus badius* & $1,2,4$ & $\mathrm{~F}$ & $\mathbf{M}$ \\
\hline Molothrus bonariensis ${ }^{*}$ & $1,2,4$ & $\mathrm{C}$ & $\mathrm{M}, \mathrm{U}$ \\
\hline Gnorimopsar chopi* & $1,2,4,5$ & $\mathrm{C}$ & S,M \\
\hline Agelaius ruficapillus* & 6 & $\mathbf{R}$ & $\mathbf{S}$ \\
\hline Icterus cayanensis* & $1,2,3,4,5$ & $F$ & $S, U$ \\
\hline Icterus icterus* & $1,2,3,4,5$ & $\mathbf{F}$ & S,U \\
\hline Leistes superciliaris* & 4 & $x$ & S \\
\hline Basileuterus flaveolus* & $2,3,5$ & $\mathbf{F}$ & S,U \\
\hline
\end{tabular}


Table 1 (cont.)

\begin{tabular}{|c|c|c|c|}
\hline Species & & Habitat & abundance \\
\hline Coereba flaveola* & $1,2,5$ & $\mathbf{U}$ & $S, U$ \\
\hline Conirostrum speciosum* & $2,3,5$ & $F$ & $S, U$ \\
\hline Euphonia chlorotica* & $1,2,3,4,5$ & $\mathrm{~F}$ & $\mathrm{~S}$ \\
\hline Thraupis sayaca* & $2,4,5$ & $x$ & $\mathrm{~S}$ \\
\hline Tachyphonus rufus* & 4 & $x$ & M \\
\hline Nemosia pileata* & $2,3,5$ & $\mathrm{~F}$ & $S, U$ \\
\hline Hemithraupis guira* & 5 & $x$ & $\mathrm{U}$ \\
\hline Sericossypha loricata* & $1,2,4,5$ & C & $\mathrm{M}$ \\
\hline Paroaria dominicana* & $1,2,4$ & C & $\mathrm{S}, \mathrm{U}$ \\
\hline Cyanocompsa brissonii* & $1,2,4$ & $\mathrm{U}$ & $S$ \\
\hline Volatinia jacarina* & 1,4 & $\mathrm{~F}$ & $\mathrm{M}, \mathrm{U}$ \\
\hline Sporophila lineola* & 4 & $\mathrm{R}$ & $S, U$ \\
\hline Sporophila nigricollis* & 1,4 & $\mathbf{R}$ & S,U \\
\hline Sporophila albogularis* & 1,4 & $\mathrm{R}$ & S,U \\
\hline Oryzoborus maximiliani & 4 & $\times$ & $S$ \\
\hline Sicalis citrina* & 1 & $x$ & $S$ \\
\hline Sicalis flaveola & 4 & $x$ & $\mathrm{~S}$ \\
\hline Spinus yarrellii & 1,4 & $x$ & $\mathrm{~S}, \mathrm{M}$ \\
\hline Coryphospingus pileatus* & $1,2,3,4,5$ & C & $\mathrm{S}, \mathrm{M}, \mathrm{U}$ \\
\hline Zonotrichia capensis* & 4 & $\mathbf{R}$ & $S, U$ \\
\hline Passer domesticus* & 4 & $\mathrm{C}$ & $\mathrm{S}, \mathrm{M}$ \\
\hline
\end{tabular}

1. Arboreal-arbustive caatinga. 2. Arboreal caatinga. 3. Angical. 4. Secondary caatinga. 5. Semideciduous forest. 6 . Water or water's edge. 7. Overhead.

$\mathrm{C}$ (common): recorded every day in some numbers. $\mathrm{F}$ (fairly common): recorded at least every other day, rarely more than a pair in a day. U (uncommon): recorded at least once a week. $R$ (rare: recorded less often than once a week. $X$ : migrants, vagrants, species with insufficient habitat; includes species seen only one to three times.

S: solitary or in pairs. M: monospecific flocks. U: mixed-species flocks.

*: observed in the park.

Sequence and taxonomy follow Sick (1985).

Species of conservation concern for which new information has been gathered are as follows.

\section{Greater Rhea Rhea americana}

Considered near-threatened by Collar and Andrew (1988). The subspecies from north-eastern Brazil ( $R$. a. americana) has declined all over its former range to the point where it has been very difficult to obtain specimens for a captive-breeding scheme (B. V. Mendes verbally 1991). It was wiped out by hunters in the general area of what is now the park in the late 1960s or early 1970s, although there is a remnant population to the north-east of the park (São João do Piaui). The species may be reintroduced in the park if adequate protection to the area is provided.

\section{Yellow-legged Tinamou Crypturellus noctivagus}

A threatened species (Collar and Andrew 1988, IBAMA 1989b), although relegated to near-threatened status in Collar et al. (1992). The subspecies which 
occurs in the park is $C$. $n$. zabele. The bird is common and widespread in the park, being frequently heard during the rainy season. It has been found in several types of vegetation but avoids open areas. Although hunted for its meat it seems to be holding its numbers.

\section{King Vulture Sarcoramphus papa}

This species is rare or absent throughout north-eastern Brazil. There are only one or two pairs in the park, which are regularly observed. One adult roosting with an immature was observed in Esperança canyon, in the southern part of the park, in July 1987, and another such pair was seen feeding on the remains of a large (around $6 \mathrm{~kg}$ ) armadillo Dasypus novemcinctus killed by a puma Felis concolor in the northern part of the park (Serra do Gongo) in July 1991.

\section{White-browed Guan Penelope jacucaca}

A threatened caatinga endemic (Sick 1985, Collar and Andrew 1988, IBAMA $1989 \mathrm{~b})$, although relegated to near-threatened status in Collar et al. (1992). This species is quite secretive and rarely seen, but is easily detected by the characteristic sound it makes with the wings during the rainy season, apparently as a courtship display. It is usually found in pairs but a group of six adult-sized birds was observed in July 1987. Most often observed in taller vegetation, including semi-deciduous forest and angical, but also in second-growth caatinga near human dwellings. The species is much sought by hunters, who lay ambushes near fruiting trees, especially Ziziphus joazeiro. The park apparently has a good population of the species, which is widespread in it.

\section{Spix's Macaw Cyanopsitta spixii}

A pair of macaws fitting the description of this very endangered species (Juniper and Yamashita 1990, Collar et al. 1992) was observed by Niéde Guidon (verbally 1991) during an archaeological survey at Serra Branca in March-April 1975. The species is apparently familiar to some local people to the north-west of the park, who are able to identify it and the Hyacinth Macaw Anodorhynchus hyacinthinus (said to occur further west) from illustrations. A villager from Angical claimed to have observed a pair of small, pale blue macaws feeding on Hymenaea fruits in early 1991, but my own surveys in the same area proved fruitless.

\section{Green-winged Macaw Ara chloroptera}

This species has disappeared from large areas of its former range, including eastern and south-eastern Brazil (Sick 1985). The park harbours a small resident population of about 20 individuals, mainly concentrated at Serra Branca, although pairs are occasionally seen in the southern part of the park. The macaws nest in natural cavities high in the cliffs, with a concentration of four pairs nesting in the same cliff near the village of Angical, at the north-western border of the park. Although nesting in the park, macaws make long foraging flights, often ranging outside the park, which makes them vulnerable to disturb- 
ance, shooting and the loss of feeding areas. I have observed them feeding on the fruits and seeds of the legumes Copaifera langsdorfii and Hymenaea courbaril, common in rocky areas.

Until recently youngsters were stolen from the nests for the pet trade, despite the danger of climbing the cliffs. Some such pet macaws are to be seen in the nearby city of São Raimundo Nonato.

\section{Blue-winged Macaw Ara maracana}

A near-threatened species according to Collar and Andrew (1988). It is very rare in the park, perhaps with only one pair present in the northern portion, especially at Varedão. Locals report it to be commoner along the Rio Piauí, a temporary river which flanks the Serra da Capivara massif (Olmos and Souza 1991). One was observed feeding on the seeds of the introduced Melia azedarach at Zabelê in December 1991.

\section{Great Horned Owl Bubo virginianus}

Reiser (1905) described the subspecies B. $v$. deserti from Juazeiro, about $300 \mathrm{~km}$ south-east of Serra da Capivara, but its taxonomic status is unclear. This owl was observed and heard in the park during 1986 and 1987, especially in the canyons, but it has not been found since. Its decline coincided with a crash in the numbers of Kerodon rupestris, a large caviomorph rodent which lives on the cliffs. Other known prey are the echimyid rodent Trichomys apereoides and the bats Artibeus planirostris and Desmodus rotundus, as recorded from regurgitated pellets.

The only other records of the species from north-eastern Brazil are from the coastal forests (Teixeira et al. 1987). If valid, B. v. deserti probably deserves conservation concern.

\section{Pygmy Nightjar Caprimulgus hirundinaceus}

This is a near-threatened caatinga endemic (Collar and Andrew 1988). The species was sporadically mist-netted but, judging from observations, it is not rare. It was observed foraging in open, disturbed areas.

Cinnamon-throated Hermit Phaethornis nattereri and Maranhão Hermit $P$. maranhoensis

Phaethornis maranhoensis has been considered to be the mature male of $P$. nattereri (Hinkelmann 1988a,b) although this view is not unanimous (Grantsau 1988). Both nattereri and maranhoensis-like individuals have been observed syntopically in the park and using the same flowers. Although not common, these hummingbirds have been observed in disturbed areas where some of their foodplants grow and appear to withstand some degree of habitat degradation. Observed food-plants are Pavonia glazioviana (Malvaceae), Helicteres muscosa (Sterculiaceae), Ruellia asperula (Acanthaceae) and Bauhinia spp. (Leguminosae). 


\section{Great Xenops Megaxenops parnaguae}

This singular and poorly known furnariid has been considered threatened (Collar and Andrew 1988, IBAMA 1989b, Collar et al. 1992). Although difficult to observe, it has a distinctive, loud vocalization (contra Teixeira et al. 1989) and can easily be located when present. It is fairly common in the park, foraging in all kings of caatinga, including low bushes in burnt areas. Nevertheless the species's needs for nesting are unknown and it is possible that it depends on taller, arboreal vegetation.

\section{Silvery-cheeked Antwren Sakesphorus cristatus}

This antbird is a near-threatened species (Collar and Andrew 1988) restricted to north-eastern Brazil (Sick 1985). It is fairly common in the park, even in secondary vegetation, usually being seen in pairs in mixed-species flocks with Great Antshrike Taraba major, antshrikes Thamnophilus spp., Black-bellied Antwren Formicivora melanogaster, White-browed Antwren Herpsilochmus pileatus and Long-billed Wren Thryothorus longirostris.

\section{White-browed Antwren Herpsilochmus pileatus}

This species was once considered threatened (Collar and Andrew 1988) after the revision of the group by Davis and O'Neill (1986), who found pileatus specimens sensu strictu from only two localities in north-eastern Brazil. However, this bird is quite common in Serra da Capivara, pairs frequently associating with mixed-species flocks. It was observed both in the semi-deciduous forest patches and all forms of caatinga, but seems to prefer taller vegetation.

The identity of the species at Serra da Capivara was confirmed by crossed play-backs of tape-recordings of both $H$. pileatus and its sister species, the Blackcapped Antwren $H$. atricapillus.

\section{White-throated Seedeater Sporophila albogularis}

A near-threatened species (Collar and Andrew 1988, though dropped as such by Collar et al. 1992) heavily trapped for the cagebird market. It is rare all over the region, recent records being only of small (up to six birds) groups or of solitary birds. Another factor contributing to the rarity of this and other seedeaters has probably been the heavy use of pesticides on pastures near the Rio Piauí. It is usually observed in open, degraded areas with grasses.

\section{Greater Large-billed Seed-finch Oryzoborus maximiliani}

This species has been considered either threatened (IBAMA 1989b) or nearthreatened (Collar and Andrew 1988, Collar et al. 1992). It is much sought-after for the cagebird market and my only record of it is an observation of a lone male at Fazenda Veneza in 1986. The species is now probably extinct in the region. 


\section{Yellow-faced Siskin Spinus yarrellii}

Another threatened species (Collar and Andrew 1988, Collar et al. 1992) which has suffered from trapping for the cagebird market and, apparently, from pesticide poisoning. It has been rarely recorded from Fazenda Veneza and the extreme north-west and south-east of the park, in both arboreal-arbustive caatinga and cultivated areas.

\section{Conservation status of Serra da Capivara National Park}

Brazilian national parks are "permanent preservation areas" protected by law from all destructive activities (Federal Decree 84,017 of 21 July 1979). As stated above a $10 \mathrm{~km}$ stretch around all parks is automatically considered a buffer zone ("environmental protection area").

Despite this legal protection, however, Serra da Capivara has no adequate statutory budget, patrolling being made by only four guards with one vehicle. The land tenure of the park has not been resolved, as about 240 families are still waiting to be compensated for losing their properties. Although some people abandoned their land, many continue to live, cultivate or raise cattle in the park. This is especially harmful at Angical and Varedão.

A management plan for the park has been completed by the staff of the Fundação Museu do Homem Americano (FUMDHAM), a non-profit scientific and environmental organization whose researchers have worked in the park since the early 1970s. Nevertheless, without a resolution of the land ownership problem and the greater involvement of the proper government agencies, the plan will be of little value.

\section{Hunting}

This is one of the worst problems in the area. Local people are very poor and consider any wild animal large enough to be eaten as a potential meal, including such creatures as skunks and pumas. Even wealthier people, including local officials, will spend weekends hunting at the Serra. Although hunting is usually directed at armadillos, any larger bird will be bagged, including doves, guans and tinamous. Hunting has already wiped out species like the Greater Rhea and giant armadillo Priodontes maximus, and put several others on the brink.

Trapping of birds for the cagebird market, including their export to other regions of the country, was more intense in the past, but still continues. The reason for the decline of this activity is the decline of the bird populations themselves. Today birds are captured mainly for the local market.

\section{Burning and grazing}

Several fires have occurred in the park, the worst of them during 1986, when all the area from the north-west border (Angical) south to Serra Branca burned during three months without any action from the authorities. Other smaller fires have occurred since in the same area. Fine forest canyons and tall arboreal 
caatinga areas were destroyed and replaced by much poorer and fire-susceptible secondary vegetation.

These fires are caused either by hunters, often as vandalism, or by farmers to create new browse for the cattle. These animals also compete with wildlife for food and water, and prevent the regeneration of some tree species, like the threatened Astronium urundeuva, by eating the seedlings.

\section{Logging}

This is a minor problem today, but still occurs sporadically. Until 1989 several clear-cuttings occurred to provide firewood for the making of lime at nearby mines. There is also selective logging of some species, especially Astronium urundeuva, Anadenanthera macrocarpa, Tabebuia impetiginosa and Diptychandra epunctata, mainly for export to other parts of the country as fence poles. The first three species, besides being listed by FAO (1986) as in danger of genetic erosion, are important components of more forest-like caatinga assemblages, especially in transitional areas between semi-deciduous forest and arborealarbustive caatinga.

\section{Discussion}

Serra da Capivara National Park and its buffer zone have a diverse bird community for a semi-arid area, including a number of migratory birds. Among the birds found in the park are most of the caatinga endemics or near-endemics and several species of conservation concern. Most of them have good populations in the park and would require no management besides effective protection of the area.

The only other caatinga reserve for which there is a published species list is Raso da Catarina Ecological Station in northern Bahia, best known for its endemic Lear's Macaws Anodorhynchus leari, with 132 species (Sick et al. 1987). Some important species, such as Pygmy Nightjar, Great Xenops, White-browed Antwren, Silvery-cheeked Antshrike, Greater Large-billed Seed-finch and Yellow-faced Siskin, apparently do not occur in Raso da Catarina, although other threatened or near-threatened species found in Serra da Capivara do, plus Lear's Macaw and the Pectoral Antwren Herpsilochmus pectoralis (a threatened species according to Collar and Andrew 1988, IBAMA 1989b, Collar et al. 1992). There is no published information on the fauna of the other caatinga reserves, Aiuaba and Seridó Ecological Stations.

The species presently at greatest risk in the Serra da Capivara park are the fringillids and macaws. The first could conceivably be reintroduced into the park, although close monitoring would be necessary to assess the possible effect of pesticide poisoning on birds under present conditions. The macaws use areas still under heavy human influence for both breeding and foraging. The largest nesting group of Green-winged Macaws (four pairs) is very near Angical, an area burnt every year. The population also seems too small to be viable in the long term.

Blue-winged Macaws regularly occur only at Varedão, at the very limit of the 
park, an area still subject to heavy grazing and agriculture. Varedão is the only canyon with an argillous soil in the region, forming pools during the rainy season and sustaining a peculiar forest dominated by $20-30 \mathrm{~m}$ high Hymenaea spp. and Tabebuia impetiginosa trees. Owing to its unique character it should be a conservation priority.

Serra da Capivara also harbours one of the most diverse floras in the caatinga domain (Emperaire 1989) and several threatened species of mammal (Olmos 1992). The park's populations of jaguar Panthera onca and white-lipped peccary Tavassu pecari may well be the last in the entire caatinga. New taxa have also been discovered in the park, including an endemic lizard, Tapinurus helenae (Manzani and Abe 1990), a nectarivorous bat (M. F. B. Souza verbally 1987) and an agouti (M. L. Lorini verbally 1991).

\section{Management priorities}

Although a management plan is already available, some urgent action needs to be taken, as the park is being rapidly degraded. After the area has been properly safeguarded, other activities stressed in the plan can be executed. At the present time it is necessary to:

1. Resolve the problem of the land tenure of the park, indemnifying owners and occupants, and removing them and their domestic animals from the park.

2. Post a minimum of 20 permanent guards, adequately equipped, and with vehicles for patrolling.

3. Install gates and signs at all entrances of the park to prevent entry by hunters in vehicles and by cattle, and construct fences in areas subject to constant invasion by cattle and near settlements to provide an easily recognized boundary for the park.

4. Consider areas adjacent to the park used by threatened species as deserving "permanent preservation", and begin studies to incorporate them into the park, with priority given to the parts of Varedão outside the park and to a 8,000 ha stretch between the park and the PI 140 road, used by most threatened species, including the Green-winged Macaw and the endangered threebanded armadillo Tolypeutes tricinctus.

\section{Acknowledgements}

This work was supported by Fundação Museu do Homem Americano, Fundação Mary Brown, Conselho Nacional de Desenvolvimento Científico e Tecnológico (CNPq) and IBAMA. Dr Niéde Guidon assisted with logistics and information about the area. Nilson Parente, Maria Fátima Barbosa Souza, Marcelo Souza, Litelton Coelho and Paulo R. Manzani assisted in fieldwork. Dr Jacques M. E. Vielliard (Arquivo Sonoro Neotropical, UNICAMP) assisted me with the preparation of reference tape-recordings and participated in the December 1989 expedition. I am greatly indebted for his advice and attention. 


\section{References}

Collar, N. J. and Andrew, P. (1988) Birds to watch: the ICBP world checklist of threatened birds. Cambridge, U.K.: International Council for Bird Preservation (Techn. Publ. 8).

Collar, N. J., Gonzaga, L. P., Krabbe, N., Madroño Nieto, A., Naranjo, L. G., Parker, T. A. and Wege, D. C. (1992) Threatened birds of the Americas: the ICBP/IUCN Red Data Book. Third edition (part 2). Cambridge, U.K.: International Council for Bird Preservation.

Davis, T. J. and O'Neill, J. P. (1986) A new species of antwren (Formicaridae: Herpsilochmus) from Peru with comments on the systematics of other members of the genus. Wilson Bull. 98: 337-352.

Emperaire, L. (1989) Végétation et gestion des resources naturelles dans la caatinga du sud-est du Piauí (Brésil). Paris: Editions de l'Orstrom TDM 52, Collection Travaux et Documents Microédités.

FAO (1986) Databook on endangered tree and shrub species and provenances. FAO Forestry Paper 77 .

Grantsau, R. (1988) Os beija-flores do Brasil. São Paulo: Mercedes-Benz.

Guidon, N. and Delibrias, G. (1986) Carbon 14 dates point to man in the Americas 32,000 years ago. Nature 32: 769-771.

Hayashi, I. (1973) A preliminary report of plant ecology of the semi-arid region in northeastern Brazil. Tokyo Geogr. Pap. 17: 95-109.

Hayashi, I. and Numata, M. (1976) Structure and succession of caatinga vegetation in the Brazilian north-east. Tokyo Geogr. Pap. 20: 23-44.

Hinkelmann, C. (1988a) On the identity of Phaethornis maranhoensis Grantsau 1968 (Trochilidae). Bull. Brit. Orn. Club 108: 14-18.

Hinkelmann, C. (1988b) Comments on recently described new species of hermit hummingbirds. Bull. Brit. Orn. Club 108: 159-169.

IBAMA (1989a) Parques nacionais, reservas biológicas e estações ecológicas. Brasília: IBAMA.

IBAMA (1989b) Lista oficial das espécies da fauna brasileira ameaçada de extinção. Portaria IBAMA 1522 de 19/09/89.

Juniper, T. and Yamashita, C. (1990) The conservation of Spix's Macaw. Oryx 24: 224228.

Lima, D. A. (1960) Estudos fitogeográficos de Pernambuco. Arq. Inst. Pesq. Agron. Pernambuco 5: 305-341.

Mares, M. A., Willig, M. R. and Lacher Jr., T. E. (1985) The Brazilian caatinga in South American zoogeography: tropical mammals in a dry region. J. Biogeogr. 12: 57-69.

Markhan, C. G. (1972) Aspectos climatológicos da seca no Brasil-nordeste. Recife: Sudene, Assessoria Técnica.

Manzani, P. R. and Abe, A. S. (1990) A new species of Tapinurus from the caatinga of Piauí, northeastern Brazil (Squamata: Tropiduridae). Herpetologica 46: 462-467.

Olmos, F. (1992) Serra da Capivara National Park and the conservation of north-eastern Brazil's caatinga. Oryx 26: 142-146.

Olmos, F. and Souza, M. F. B. (1991) Cayman crocodilus in the caatinga of southeastern Piauí, Brazil. Herp. Rev. 22: 28-29.

Reis, A. C. (1976) Clima da caatinga. An. Acad. Bras. Cienc. 48: 325-335.

Reiser, O. (1905) Bericht über die ornitologische Ausbeute wahrend der von der K. Akademie der Wissenschaften in Jahre 1903 nach Brasilien entsendetem Expedition. Anz. K. Akad. Wissensch. Wien, Math. Naturw. 52(18): 320-326.

Rodrigues, M. T. (1991a) Herpetofauna das dunas interiores do rio São Francisco. I. Introdução à área e descrição de um novo gênero de microteiideos (Calyptommatus) com notas sobre sua ecologia, distribuição e especiação (Sauria, Teiidae). Pap. Avuls. Zool. S. Paulo 37: 285-320. 
Rodrigues, M. T. (1991b) Herpetofauna das dunas interiores do rio São Francisco. II. Psilophthalmus: um novo gênero de microteiidae sem pálpebras (Sauria, Teiidae). Pap. Avuls. Zool. S. Paulo 37: 321-327.

Rodrigues, M. T. (1991c) Herpetofauna das dunas interiores do rio São Francisco. III. Procellosaurinus: um novo gênero de microteiidae sem pálpebras, com redefinição do gênero Gymnophthalmus (Sauria, Teiidae). Pap. Avuls. Zool. S. Paolo 37: 329-342.

Rodrigues, M. T. (1991d) Herpetofauna das dunas interiores do rio São Francisco. IV. Uma nova espécie de Typhlops (Ophidia, Typhlopidae). Pap. Avuls. Zool. S. Paulo 37: $343-346$.

Sarmiento, G. (1975) The dry plant formations of South America and their floristic connections. J. Biogeogr. 2: 233-253.

Sick, H. (1985) Ornitologia brasileira: uma introdução. Brasília: Editora Universidade de Brasília.

Sick, H., Gonzaga, L. P. and Teixeira, D. M. (1987) A arara azul de Lear Anodorhynchus leari Bonaparte, 1856. Rev. Bras. Zool. 3: 441-463.

Stotz, D. F. and Bierregaard Jr., R. O. (1989) The birds of Fazendas Porto Alegre, Esteio and Dimona north of Manaus, Amazonas, Brazil. Rev. Bras. Biol. 49: 861-872.

Teixeira, D. M., Nacinovic, J. B. and Tavares, M. S. (1986) Notes on some birds of north-eastern Brazil. Bull. Brit. Orn. Club 106: 70-74.

Teixeira, D. M., Nacinovic, J. B. and Pontual, J. B. (1987) Notes on some birds of northeastern Brazil (2). Bull. Brit. Orn. Club 107: 151-156.

Teixeira, D. M., Nacinovic, J. B. and Luigi, G. (1989) Notes on some birds of northeastern Brazil (4). Bull. Brit. Orn. Club 109: 152-157.

Vanzolini, P. E. (1991a) Two new species of Amphisbaena from the fossil dune fields of the middle Rio São Francisco, state of Bahia, Brazil (Reptilia, Amphisbaenia). Pap. Avuls. Zool. S. Paulo 37: 259-276.

Vanzolini, P. E. (1991b) Two further new species of Amphisbaena from the semi-arid northeast of Brazil (Reptilia, Amphisbaenia). Pap. Avuls. Zool. S. Paulo 37: 347-361.

Webb, K. (1974) The changing face of north-eastern Brazil. New York: Columbia University Press.

\section{FABIO OLMOS}

Fundação Museu do Homem Americano, FUMDHAM, São Raimundo Nonato, PI, 64770-ooo, Brazil. Present address: Parque Estadual de Ilhabela, Rua Morro da Cruz 608, Ilhabela, SP 11630-0oo, Brazil. 